9 Gambrell RD Jr. The prevention of endometrial cancer in postmenopausal women with progestogens. Maturitas 1978;i:107-12.

10 Royal College of General Practitioners. Oral contraception study. Effect on hypertension and benign breast disease of the progestogen component in combined oral contraceptives. Lancet $1977 ; \mathrm{i}: 624$.

11 Kay CR. The happiness pill. 7 R Coll Gen Pract 1980;30:8-19.

12 Meade TW, Greenberg G, Thompson SG. Progestogens and cardiovascular reactions associated with oral contraceptives and a comparison of the safety of 50 and $30 \mu \mathrm{g}$ oestrogen preparations. $\mathrm{Br} \mathrm{Med} \mathcal{F} 1980$; 280:1157-61.

13 National Institutes of Health/National Institute on Aging. Estrogen use in postmenopausal women. Consensus conference on aging, Bethesda, Maryland, USA, 13-14 September 1979.

14 Spellacy WN, Buhi WC, Burk SA. Effects of norethindrone on carbohydrate and lipid metabolism. Obstet Gynecol 1975;46:560-3.

15 Spellacy WN, Buhi WC, Burk SA. Prospective studies of carbohydrate metabolism in "normal" women using norgestrel for eighteen months. Fertil Steril $1981 ; 35: 167-71$.

16 Bradley DD, Wingerd S, Petitti DB, Krauss RM, Ramcharan S. Serum high density lipoprotein cholesterol in women using oral contraceptives, estrogens and progestins. $N$ Engl 7 Med 1978;299:17-20.

17 Larsson-Cohn U, Fahraeus L, Wallentin L, Zador G. Lipoprotein changes may be minimized by proper composition of a combined oral contraceptive. Fertil Steril $1981 ; 35: 172-9$.

${ }^{18}$ Gordon T, Castelli WP, Hjortland MC, Kannel WB, Dawber TR. High density lipoprotein as a protective factor against coronary heart disease. Am $\mathcal{F}$ Med 1977;62:707-14.

19 Yaari S, Goldbourt U, Even-Zohar S, Neufeld HN. Associations of serum high density lipoprotein and total cholesterol with cardiovascular and cancer mortality in a 7 year prospective study of 10,000 men. Lancet $1981 ;$ i :1011-5.

${ }^{20}$ Ross RK, Paganini-Hill A, Mack TM, Arthur M, Henderson BE. Menopausal oestrogen therapy and protection from death from ischaemic heart disease. Lancet 1981 ; : $: 858-60$.

${ }^{21}$ Fahreus L, Larsson-Cohn U, Wallentin L. Gestageners inverkan pa lipoproteiner hos patienter med postmenopausal oestrogen behandling. Svenska Läkaresällskapets Handlingar; Acta Societatis medicorum Suecanae 1981;90:5. (Abstract 19P, p 384.)

22 Kalkhoff RK. Metabolic effects of progesterone. Am 7 Obstet Gynecol $1982 ; 142: 735-8$

23 Whitehead MI, Townsend PT, Gill DK, Collins WP, Campbell S. Absorption and metabolism of oral progesterone. $\mathrm{Br} \mathrm{Med} \mathcal{F} 1980 ; \mathbf{2 8 0}$ : 825-7.

24 Anonymous. Br Med $\mathcal{F} 1981 ; 282: 736-7$

25 Whitehead MI, Townsend PT, Pryse-Davies J, et al. Effects of various types and dosages of progestogens on the postmenopausal endometrium. Reprod Med 1982;27:539-48.

${ }^{26} \mathrm{~K}$ ing RJB, Townsend PT, Whitehead MI. The role of estradiol dehydrogenase in mediating progestin effects on endometrium from postmenopausal women receiving estrogens and progestins. F Steroid Biochem $1981 ; 14: 235-8$.

${ }^{27}$ King RJB, Whitehead MI, Campbell S, Minardi J. Effect of estrogen and progestin treatments on endometria from postmenopausal women. Cancer Res 1979;39:1094-1101.

${ }^{28}$ Smith JA, King RJB, Meggitt BF, Allen LN. Biochemical studies on human and rat breast tissues. Br f Cancer 1966;20:335-44.

(Accepted 26 fuly 1983)

\title{
Propranolol as a novel, effective spermicide: preliminary findings
}

\author{
J ZIPPER， R G WHEELER，D M POTTS， M RIVERA
}

\begin{abstract}
The efficacy and tolerability of $80 \mathrm{mg}$ propranolol tablets as a vaginal contraceptive were studied in 198 fertile women for 11 months. The calculated one year life table pregnancy rate was $3 \cdot 4 / 100$ women and the Pearl index was $3.9 / 100$ women years. No major adverse effects were encountered.

The findings suggested that propranolol is an effective vaginal contraceptive whose failure rate compares favourably with that of other methods of contraception. Further study of propranolol and similar compounds is warranted.
\end{abstract}

\section{Introduction}

Spermicides are biologically an obvious way of interrupting human fertility and should be convenient to use. The contribution of vaginal spermicides to contraception is becoming more

\footnotetext{
Department of Physiology and Biophysics, School of Medicine, University of Chile, Casilla 6524, Santiago, Chile

J ZIPPER, MD, professor

Family Health International, Research Triangle Park, NC 27709, USA

R G WHEELER, MENG, director of quality assurance

D M POTTS, MB, PHD, president

Hospital Sotero del Rio, Santiago, Chile

M RIVERA, midwife

Correspondence and requests for reprints to: Dr D M Potts.
}

widespread $^{1}$ but there has been a reduction in the number of products available over the past two decades. ${ }^{2}$ Advantages of spermicides include safety, availability, simplicity, convenience, and acceptability. In addition, they are appropriate for short term use or for use in conjunction with other methods. Unfortunately, however, their failure rate compared with other forms of contraception and the need to apply them shortly before intercourse limit their use and usefulness. Hence there is a need to develop novel, effective agents as spermicidal contraceptives.

Nonoxynol 9 is the active ingredient most widely used in spermicides. Chvapil et al reported liver toxicity in animals when nonoxynol 9 was injected intraperitoneally. ${ }^{3}$ Some investigators found that women who received nonoxynol 9 per vaginam for 14 days had a reduction in their serum cholesterol concentration but no changes in other values reflecting liver function. ${ }^{4}$ In another study in women with a smaller dose of nonoxynol 9 applied per vaginam, however, these findings were disputed. ${ }^{5}$ Currently no analytical method is available to identify and quantify nonoxynol 9 in human tissues, although studies in rabbits with ${ }^{14} \mathrm{C}$-nonoxynol 9 indicate that it is extensively absorbed from the vagina. ${ }^{3}$

Quinine, the dextro isomer of quinidine, has long been used in Europe as a vaginal spermicide, albeit a rather ineffective one. ${ }^{6}$ In 1973 propranolol, chlorpromazine, phenoxybenzamine, and other drugs were reported to inhibit the motility of spermatozoa in vitro. ${ }^{7}$ The property common to these drugs is membrane stabilising activity. Both the racemic dextrolaevo mixture and the dextro isomer of propranolol were shown to inhibit sperm motility. ${ }^{7}$ This suggests that the effect on sperm motility is independent of beta receptor blockade, since D-propranolol has only very weak beta receptor blocking properties. Although membrane stabilising activity has in the past been used synonymously with local anaesthetic activity, it is apparent that there is a 
need to redefine and separate these properties. ${ }^{8}$ The concentration of propranolol which will inhibit sperm motility by $50 \%$ is $0.8 \mathrm{mmol} / \mathrm{l}(27 \mathrm{mg} / 100 \mathrm{ml}) .^{9}$

In animals propranolol applied topically to the vagina prevented conception, ${ }^{10}$ and we therefore decided to evaluate the efficacy and tolerability of propranolol as a vaginal contraceptive.

\section{Patients and methods}

A total of 198 sexually active parous non-lactating women volunteers were recruited in the family planning clinic of the Hospital Sotero del Rio in Santiago. Their ages ranged from 15 to 42 years (mean 26, SD $5 \cdot 6$ years). All had restarted regular menstrual cycles since their last pregnancy and, having had intrauterine contraceptive devices fitted, wished to change to another form of contraception. The study continued for 11 months. Each evening from the last day of menstruation until the first day of the next mentrual period they inserted a commercially available $80 \mathrm{mg}$ tablet of DL-(racemic)-propranolol into the vagina. Placement in the evening was routine whether intercourse took place in the morning or evening. No other method of contraception was used during the study.

The volunteers were reviewed after the first month of treatment and then at three monthly intervals. The pattern of menstruation, symptomatic side effects, and reasons for discontinuation were inquired for and failures documented. The data were analysed by a BDMP statistical package, which was used to calculate life table rates (survival analysis). ${ }^{11}$ In a subgroup of 30 women spinbarkeit tests were performed at between days 12 and 14 of the menstrual cycle and postcoital tests were performed on the first day that the cervical mucus was penetrable. These women were asked to insert the propranolol tablet at $9 \mathrm{pm}$ and have intercourse at about $7 \mathrm{am}$ on the morning of the postcoital test. The spermatozoa in the cervix were sampled and examined about three hours after intercourse.

\section{Results}

There were no noticeable effects on menstruation and no systemic adverse reactions were noted. Discontinuation because of local itching or discomfort occurred mainly in the first three months of treatment, and any such complaint was generally rated as mild. A total of 127 women years of exposure was documented (table). The calculated

Eleven month cumulative life table rates for intravaginal propranolol contraception $(n=198)$

\begin{tabular}{lccc}
\hline & & \multicolumn{2}{c}{ Rate } \\
\cline { 3 - 4 } & No & Mean & SE \\
\hline Accidental pregnancies & 5 & $3 \cdot 15^{*}$ & $1 \cdot 6$ \\
Reason for discontinuation: & 33 & $18 \cdot 0$ & $2 \cdot 9$ \\
Itching or pain & 10 & 6.1 & $1 \cdot 9$ \\
Personal reasons & 30 & $15 \cdot 0$ & \\
Lost to follow up & & & \\
\hline
\end{tabular}

*Corresponds to $3 \cdot 4 / 12$ months.

life table pregnancy rate at one year was $3 \cdot 4 / 100$ women and the Pearl index was $3 \cdot 9 / 100$ women years. The five women who became pregnant were not among those in whom postcoital testing was performed. All of those who became pregnant chose to terminate their pregnancy by abortion. No abnormalities were noted in the fetuses. Probably none of the women who were lost to follow up became pregnant, since they would have come to the Hospital Sotero del Rio for pregnancy testing and management. Postcoital testing did not show any motile spermatozoa in the endocervical samples.

\section{Discussion}

The expected cumulative rate of conception 12 months after removal of an intrauterine contraceptive device is $88.2 / 100$ women. ${ }^{12}$ Our results suggest that propranolol is an effective vaginal contraceptive whose in use failure rate compares favourably with that of other methods of contraception. It appears that sperm motility is inhibited whether intercourse occurs shortly after insertion of the tablet or is delayed for up to 10 hours. Tests detecting only immotile sperm in cervical fluids, however, may indicate that fertilisation is unlikely but not that it is impossible. ${ }^{13}$

Clinical trials typically report some complaints of discomfort and discontinuations with vaginal spermicides, but rates vary widely even for the same product. For example, only $2.6 \%$ of Japanese users complained of irritation with Neo-Sampoon tablets compared with over $75 \%$ of Filipino women using the same product. ${ }^{1}$

In addition to the effect on sperm motility, propranolol prevents implantation in animals. ${ }^{10}$ Since propranolol is extensively absorbed from the vagina, ${ }^{14}$ it is possible that its effect may be at least partly mediated by some systemic action. We suggest that further studies should be instituted to investigate the potential of this and similar compounds as vaginal contraceptives.

We thank Dr R M Pearson, of St Bartholomew's Hospital, London, and Dr W Castle, of Imperial Chemical Industries Ltd, UK, for help and advice during the preparation of this article.

\section{References}

${ }^{1}$ Coleman S, Piotrow PT. Spermicides-simplicity and safety are major assets. Popul Rep [H] 1979; No 5:77-120.

${ }^{2}$ Hardy NR, Wood C. Vaginal contraception. In: Potts M, Wood C, eds. New concepts in contraception. Oxford, Lancaster: Medical and Technical Publishing, 1972:103-23.

${ }^{3}$ Chvapil M, Eskelson CD, Droegemueller W, et al. New data on the pharmacokinetics of nonoxynol-9. In: Zatuchni GI, Sobrero AJ, Speidel JJ, Sciarra JJ, eds. Vaginal contraception: proceedings of an international workshop on new developments in vaginal contraception, Guatemala City, 1979. Hagerstown, MD: Harper and Row, 1979:165-74.

${ }^{4}$ Chvapil M, Droegemueller W, Earnest DL. Liver function tests in women using intravaginal spermicide nonoxynol-9. Fertil Steril $1982 ; 37: 281-2$.

${ }^{5}$ Malyk B. Preliminary results: serum chemistry values before and after the intravaginal administration of $5 \%$ nonoxynol-9 cream. Fertil Steril $1981 ; 35: 647-52$.

${ }^{6}$ Peel J. Manufacture and retailing of contraceptives in England. Population Studies 1963;17:113-25.

? Peterson RN, Freund M. Effects of $\left(\mathrm{H}^{+}\right),(\mathrm{Na}),(\mathrm{K} \cdot)$ and certain membrane active drugs on glycolysis, motility, and ATP synthesis by human spermatozoa. Biol Reprod 1973;8:350-7.

${ }^{8}$ Smith $\mathrm{HJ}$. The need to redefine membrane stabilising activity of betaadrenergic receptor antagonists. $\mathcal{F}$ Mol Cell Cardiol 1982;14:495-500.

${ }^{9}$ Hong CY, Chaput de Saintonge DM, Turner P. The inhibitory action of procaine, ( )-propranolol and $( \pm)$-propranolol on human sperm motility: antagonism by caffeine. Br f Clin Pharmacol 1981;12:751-3.

10 Zipper J, Bruzzone ME, Angelo S, Munoz V, Wheeler RG. Effect of topically applied adrenergic blockers on fertility. Int $\mathcal{F}$ Fertil 1982;27: 242-5.

${ }^{11}$ Benedetti J, Yuen K, Young L. Life tables and survival functions. In: Dixon WJ, ed. BDMP statistical sof tware. Berkeley, Los Angeles, London University of California Press, 1981 :557-75.

12. Tietze C, Lewit S. Evaluation of intrauterine devices. Stud Fam Plann $1970 ;$ No $55: 1-40$

${ }^{13}$ Zaneveld LJD, Bhattacharya AK, Kim DS, Schumacher GFB, Beluhan Z. Primate model for evaluation of vaginal contraceptives. Am $\mathcal{F}$ Obstet Gynecol 1977;129:368-73.

14 Patel LG, Warrington SJ, Pearson RM. Propranolol concentrations in plasma after vaginal administration. $B r \operatorname{Med} \mathcal{F} 1983 ; 287: 1247-8$.

(Accepted 9 September 1983)

ONE HUNDRED YEARS AGO SIR,-There is a doctor in this town who displays two large red gas-lamps outside his house, with his name thereon, presumably for the purpose of advertisement. May I ask you, sir, for your opinion upon the matter, as to whether you think it decent or professional, and if it is not tending to degrade the medical man in the eyes of the public ?-I am, sir, yours truly, MT.

** The use of red lamps by medical men seems to be a survival of the custom of distinguishing shops by sign-boards, which was at one time universal, and was doubtless common among apothecaries. It is a custom possibly "more honoured in the breach than the observance" at the present time, but we are not prepared to say that it is unprofessional, nor that anyone who follows it deserved to be gibbeted. (British Medical fournal 1883;i:850.) 